\title{
CYBERNETIC FUNCTIONING IN STUTTERING
}

\author{
URSULA ZSILA VECZ M (LOG) PRETORIA \\ Department of Speech Science, Speech Pathology and Audiology, University of Pretoria
}

\section{SUMMARY}

The aim of this study was to evaluate different kinds of masking noise and DAF, in order to identify the condition which would elicit the highest incidence of fluency in a group of stutterers. The study demonstrates that masking noise and DAF can be effectively applied as an aid in a therapy programme, viz. noise can effectively be put to use so as to encourage and reinforce somesthesia. Stuttering is viewed as defective functioning in the cybernetic system.

\section{OPSOMMING}

Hierdie studie evalueer verskeie tipes maskering sowel as vertraagde ouditiewe terugvoering om sodoende die tipe lawaai wat die hoogste persentasie vlotheid in 'n groep hakkelaars teweegbring, te identifiseer. Hierdie studie poog ook om te bewys dat maskering en vertraagde ouditiewe terugvoering effektiewelik in terapieprogramme toegepas kan word, $\mathrm{nl}$. om somestetiese terugvoering te versterk. Hakkel word beskou as afwykende funksionering in die kubernetiese sisteem.

In an attempt to obtain a better understanding of stuttering, a number of investigators have attempted to find the cause of the problem and an appropriate "cure". Many of the theories offer reasonably adequate explanations for stuttering but cures posited only provide temporary relief from stuttering.

The view that the stutterer may have a malfunctioning, or a defect in the auditory feedback system and the fact that noise had an ameliorative effect on the stuttering, resulted in the development of portable devices emitting masking noise or delayed auditory feedback (DAF) in an attempt to eliminate stuttering.

Some researchers in the field of stuttering have cautioned that it is a much more complex matter than just investigating the auditory feedback system and applying masking noise or DAF to elicit a higher percentage of fluency. This view of stuttering is limited as it does not adequately account for the disruption of the motor sequences of stuttered words. Yet researchers often advise the incorporation of masking noise and DAF as a part of the therapeutic programme.

Van Riper ${ }^{14}$ sums up the situation in which attempts have been made to simply alter the auditory signals by using masking noise and DAF as a clinical procedure as follows: exchanging stuttering for deafness is no great bargain and we have found little permanent improvement as a result of masking itself.

Van Riper ${ }^{13}$ emphasizes therapeutic procedures involving the retraining of speech monitoring by means 'of employing auditory signals which exclude the perception of the stutterer's own speech. By means of 
masking noise and DAF fluency can be manipulated and then reinforced.

In view of previous research studies, the writer attempted to evaluate the influence of different types of masking noise and delayed auditory feedback on the speech of stutterers. The main aim was to identify the type of masking noise and/or delayed auditory feedback which would elicit the highest incidence of fluency in view of reinforcing normal motor patterns and enhancing somesthetic feedback.

\section{EXPERIMENTAL DESIGN}

Many different fragments and facets of information have to be brought together comprehensively to identify conclusively the most appropriate and successful type of masking dèvice to be used in therapy as an aid so as to reinforce somesthesia. Certain hypotheses can be postulated stemming from the results of previous research in this field.

\section{HYPOTHESES}

The degree of fluency in stutterers can be increased by application of masking noise and DAF. Previous studies described devices which were developed in an attempt to ameliorate stuttering. Devices were developed by Trotter and Lesch ${ }^{12}$, Curlee and Perkins ${ }^{4}$, Dewar et al ${ }^{5}$ and Van Riper. ${ }^{14}$.

Continuous masking noise and DAF elicits a higher degree of fluency than intermittent masking noise. Van Riper ${ }^{14}$ has determined that when stutterers are exposed to intermittent noise, they still tend to anticipate and expect to stutter; as a result, stuttering does in fact ensue and thus the frequency of stuttering is not diminished dramatically. These findings are in agreement with those of Altrows and Bryden. ${ }^{1}$

Continuous masking noise obtained by using the Bench Model Type Edinburgh Masker is more successful than continuous white noise as research has indicated that low frequency noise is more successful in masking the speaker's own voice (Cherry and Sayers ${ }^{3}$ ). White noise contains a wider spectrum of frequencies.

Persons with a severe stuttering problem will not necessarily have poorer oral perceptual abilities (Jensen et $\mathrm{al}^{7}$ ). To a large extent previous research has been conducted in cases of severe neurological deprivation such as dysarthria or cleft palate. Limited research has indicated that stutterers need not necessarily function poorly on oral perceptual tasks.

\section{SUBJECTS}

In view of evaluating various devices and techniques which can alter the auditory feedback signals it was necessary to select a group of subjects, representative of the population of stutterers. For the purposes of this study 14 subjects were chosen at random, all fulfilling certain criteria, thus forming a homogenous group. (see Table I) 
TABLE I: The criteria set for the fourteen subjects

\begin{tabular}{|c|cc|c|c|c|c|c|}
\hline Subject & Age & $\begin{array}{c}\text { Degree of } \\
\text { speech } \\
\text { defect }\end{array}$ & $\begin{array}{c}\text { Home } \\
\text { language }\end{array}$ & Sex & $\begin{array}{c}\text { Status } \\
\text { of } \\
\text { hearing }\end{array}$ & $\begin{array}{c}\text { Oral } \\
\text { status }\end{array}$ \\
\hline & yrs & mnths & & & & & \\
1 & 21 & 4 & v. severe & Afr. & Male & Normal & Normal \\
2 & 19 & 9 & severe & Afr. & Male & Normal & Normal \\
3 & 37 & 6 & severe & Eng. & Male & Normal & Normal \\
4 & 23 & 11 & v. severe & Afr. & Male & Normal & Normal \\
5 & 20 & 10 & severe & Afr. & Male & Normal & Normal \\
6 & 34 & 5 & severe & Afr. & Male & Normal & Normal \\
7 & 23 & 2 & v. severe & Afr. & Male & Normal & Normal \\
8 & 28 & 6 & v. severe & Afr. & Female & Normal & Normal \\
9 & 30 & 1 & v. severe & Afr. & Male & Normal & Normal \\
10 & 16 & 0 & v. severe & Afr. & Male & Normal & Normal \\
11 & 36 & 0 & v. severe & Afr. & Male & Normal & Normal \\
12 & 24 & 6 & v. severe & Afr. & Male & Normal & Normal \\
13 & 19 & 6 & severe & Eng. & Male & Normal & Normal \\
14 & 27 & 9 & severe & Afr. & Male & Normal & Normal \\
\cline { 4 - 6 }
\end{tabular}

\section{EQUIPMENT AND APPARATUS}

In order to compare and evaluate equipment and devices which could alter the auditory feedback signals, devices offering different kinds of auditory feedback were included in the study. Equipment offering continuous masking noise including the Edinburgh Master (Bench Model - Type CM3) and white noise, achieved by employing the Maico, Model MA.24 audiometer Automatic intermittent noise was obtained by the Edinburgh Masker (Portable Model - Type AF1). DAF was achieved employing the 'Artik,' device, similarly used in a study by Martin and Haroldson. ${ }^{8}$

The minimum intensity output used in the experiment was $100 \mathrm{~dB}$ SPL, for all the masking noise devices. The intensity required for DAF is the most comfortable loudness level. In the case of the study the intensity output, however, was also $100 \mathrm{~dB}$ SPL. Both types of the Edinburgh Masker Models produced a masking noise comprising a frequency of $150 \mathrm{~Hz}$. This meets with the requirements, discussed by Cherry and Sayers ${ }^{3}$, that effective masking noise comprises a low frequency - i.e. below $500 \mathrm{~Hz}$ and that the intensity must be a minimum of $40 \mathrm{~dB}$ above normal voice production level. The delay time of the 'Artik' device was 0,13 seconds.

The two tests included for oral-perceptual ability', as similarly described by Jensen et $\mathrm{al}^{7}$ in their study were oral stereognosis and two-point discrimination. Ten of the forms of the set of 25 developed by the National Institute of Dental: Research (Grossman ${ }^{6}$ ) were used for testing oral stereognosis. A Vernier Caliper, which was similarly adapted in the experiments by Rutherford and $\mathrm{McCall}^{10}$ was used for the test of two-point discrimination.:

In order to determine that all the equipment meets with the minimum 
intensity required for effective noise the devices were calibrated with the Brüel-Kjaer sound pressure level meter.

EXPERIMENTAL DESIGN AND PROCEDURE

The investigator drew up a comprehensive and strict plan so as to ensure that all behaviour could accurately be accounted for. The investigator saw the subjects over a period of 5 weeks. A minimum time lapse of $4 \frac{1}{2}$ hours has to be permitted before the next experimental situation so as to avoid carry over fluency. It also suited the patients better to come to the Clinic once a week.

Initially a videotaped recording was made of each subject's spontaneous speech under normal feedback conditions. Hereafter, each subject was exposed to one of the four different experimental conditions, which were also videotaped in a soundproof room.

In order to elicit an adequate sample of spontaneous speech the investigator used the "Job Task" as described by Johnson et al and Van Riper. ${ }^{13}$ The subjects were required to discuss controversial subjects so as to elicit a minimum of 400 utterances or \pm 10 stuttering moments (Van Riper ${ }^{13}$ ). After each videotaped recording was analysed and evaluated according to the "Profile of Stuttering Severity" (Van Riper ${ }^{13}$ ). Lastly, oral stereognostic ability and twopoint discrimination was evaluated on the 14 stuttering subjects.

\section{STATISTICAL ANALYSIS}

The methods employed to evaluate the results were the "Wilcoxon Signed-Rank Test", also known as the "One Sample Wilcoxon's Test". The "Sign Test" was employed in evaluating the results obtained on test for oral stereognosis $\left(\right.$ Siegel ${ }^{11}$ ).

The information for statistical analysis was obtained from each profile for each experimental condition of the subjects. The investigator had to determine the category improvement of each characteristic on the "Profile of Stuttering Severity" (frequency, tension, duration and avoidance-postponement behaviour) when compared to the same characteristic on the profile for the control situation.

\section{RESULTS AND CONCLUSIONS}

It was ascertained and proved that continuous masking noise and DAF elicited the highest incidence of fluency, in comparison to automatic intermittent masking noise. With regard to the evaluation of continuous masking noise and DAF, white noise and DAF elicited more fluency, than continuous masking noise emitted by the Edinburgh Masker - Bench Model.

Stuttering behaviour which was effected by masking noise and DAF was fequency of stuttering, duration of the stuttering moment and tension. Postponement-avoidance behaviour was hardly effected in most cases of masking noise and DAF.

Subjective observation confirms that masking noise and DAF de-

Die Suid-Afrikaanse Tydskrif vir Kommunikasieafwykings, Vol. 28, 1981 
creases the incidence of stuttering but does not totally ameliorate stuttering behaviour. (see Table II)

TABLE II: A Summary of the effects of the four experimental conditions on the speech of the 14 subjects

\begin{tabular}{|l|l|l|l|l|}
\hline $\begin{array}{l}\text { Characteristics } \\
\text { of stuttering }\end{array}$ & $\begin{array}{l}\text { Continuous } \\
\text { Noisc } \\
\text { Edinburgh } \\
\text { Masker } \\
\text { (Bench Model) }\end{array}$ & White noise & D A F & $\begin{array}{l}\text { Automatic } \\
\text { intermittent } \\
\text { noise }\end{array}$ \\
\hline Frequency & Slight & Significant & Dramatic & Slight \\
\hline Tension & Slight & Moderate & Significant & Slight \\
\hline Duration & Slight & Moderate & Dramatic & Slight \\
\hline $\begin{array}{l}\text { Avoidance- } \\
\text { postponement }\end{array}$ & Significant & Moderate & Dramatic & No \\
\hline
\end{tabular}

The investigator observed change in vocal intensity, vocal pitch and rate of speech when the subjects were exposed to the experimental conditions. Drawling of speech also occurred.

It is important to note that each subject exhibited a different and personal profile under each experimental condition, thus emphasizing that therapy programmes must cater for the individual's needs.

From the results in this experiment it appears that persons with a severe stuttering problem tend to make more errors in oral stereognostic testing, than normal fluent speakers. (For this experimental condition a group of normal fluent speakers was selected to match the stutterers, as no norms are available.)

Persons with a severe stuttering problem have good two-point discrimination ability, they fall within the norm determined by Ringel and Ewanowski $i^{9}$ for normal fluent speakers, i.e. $1,0 \mathrm{~mm}$ $-2,0 \mathrm{~mm}$.

It appears that subjects who achieve a greater increase of fluency with masking noise and DAF do not necessarily have good oral perceptual ability. Some subjects who did not show dramatic increase of fluency when using masking noise and DAF on the contrary had good oral perceptual ability.

It has become increasingly clear that a solution for stuttering does not merely lie in altering the auditory feedback of stutterers or is developing more level and sophisticated devices. On the contrary older methods of masking auditory feedback (such as white noise) have been proved more effective.: The findings in this study also support the view that somesthetic feedback requires attention in therapy, as well as in future research.

Supplying the person who stutters with a device which produces 
sufficient high intensity noise to alter the perception of his own speech and elicit a higher incidence of fluency seems a very simple and easy way to solve the problem. Unfortunately as soon as the stutterer switches off the masking device, stuttering once again increases. Another disadvantage of these devices is that they do not elicit total fluency, nor are they comfortable to wear and they often elicit a negative reaction from listeners who treat a stutterer wearing a device as though he were hard of hearing.

Unfortunately only a limited amount of work has been done in this field and not much information is available. It is possible that stutterers tend to achieve poorer results on oral stereognosis because they are not used to employing this feedback system in speech production. From the results in this study and previous research it can be argued that a normal "fluent" speaker may also exhibit errors on this type of oral perceptual testing; the stutterer in turn may exhibit good results on oral perceptual testing. These types of tests may not truly be testing oral perceptual ability but merely tactile sensations.

In other words, oral perceptual ability is not directly related to somesthesia but a separate feedback ability therefore stutterers as a group should generally compare well with "normal" fluent speakers. Furthermore, this accounts... for the phenomenon that stutterers can achieve a higher degree of fluency under -specific circumstances - when given the opportunity, e.g. to use masking noise. The motor patterns required for fluent speech are available, but the stutterer has not learned to apply these in his normal speech production, as the change-over from auditory feedback to somesthetic feedback, which generally occurs during normal development has not taken place. Once a higher degree of fluency has been elicited these normal motor patterns must be reinforced so that they can gradually become habitual.

Many "solutions" and therapy programmes fail, because these do not emphasize or reinforce awareness of normal use of fluent speech patterns. Stuttering may well result from failure to learn the essential skills at the beginning of speech development. Bluemel's ${ }^{2}$ comment aptly sums this up: Speech which is poorly made is readily unmade.

\section{ACKNOWLEDGEMENTS}

Dr. I. C. Uys and Prof. I. S. Hay, Dept. of Speech Pathology and Audiology, University of Pretoria, for their invaluable guidance in preparing this study.

Prof. D. J. Stoker, Human Sciences Research Council, Pretoria, for helping with the statistical planning and analysis of the research.

Die Suid-Afrikaanse Tydskrif vir Kommunikasieafwykings, Vol. 28, 1981 


\section{REFERENCES}

1. Altrows, I. and Bryden, M. P. (1977): Temporal Factors in the Effects of Masking Noise on the Fluency of Stutterers. Journal of Communication Disorders, Vol. 10, pp. 315-329.

2. Bluemel, C. S. (1957): The Riddle of Stuttering, Danville Illinois, The Interstate Publishing Co.

3. Cherry, E. C. and Sayers, B. M. (1956): Experiments on the total Inhibition of Stammering by External Control and some Clinical Results. Journal of Psychosomatic Research. Vol. 1, pp. 223-246.

4. Curlee, R. F. and Perkins, W. H. (1973): Effectiveness of DAF Conditioning Programme for Adolescent and Adult Stutterers, Beh. Res. Therapy. Vol. 11, pp. 395-401.

5. Bewar, A. et al (1976): Automatic Triggering of Auditory Feedback Masking in Stammering and Cluttering, British Journal of Disorders of Communication. Vol. 11, 1, pp. 19-26.

6. Grossman, R. C. (1967): Methods of Determining Oral Tactile Experience. Chap. 8. In Symposium. Bosma, J. F. (Ed.), Springfield, Charles C. Thomas Publishers.

7. Jensen, P. J. et al (1975): Oral Sensory-Perceptual Integrity of Stutterers. Folia Phoniatrica. Vol. 27, pp. 38-45.

8. Martin, R. and Haroldson, S. (1969): The Effects of Two Treatment Procedures on Stuttering. Journal of Communication Disorders. Vol 2, pp. 115-125.

9. Ringel, R. L. and Ewanowski, S. J. (1963): Oral Perception, Two-Point Discrimination. JSHR. Vol. 8, pp. 389-398.

10. Rutherford, D. and McCall, G. (1967): Testing Oral Sensation and Perception in Persons with Dysarthria. In Symposium. Bosma, J. F. pp. 188-200.

11. Siegel, S. (1956): Nonparametric Statistics for the Behavioural Sciences. New York, McGraw-Hill.

12. Trotter, W. D. and Lesch, M. M. (1967): Personal Experiences with a Stutter Aid. JSHD. Vol. 32, 3, pp. 271-272.

13. Van Riper, C. (1971): The Nature of Stuttering. Englewood Cliffs, N. J., Prentice Hall.

14. Van Riper, C. (1973): The Treatment of Stuttering. Englewood Cliffs, N. J., Prentice-Hall. 


\title{
AUDIOMETERS IMPEDANCE METERS
}

\author{
LIGHT, \\ PORTABLE, \\ SCREENING AND CLINICAL, \\ MANUAL AND AUTOMATIC \\ PHONIC EAR F.M. \\ TEACHING SYSTEMS WITH \\ PHONAK AUDIO-INPUT \\ HEARING AIDS
}

\section{NEEDLER WESTDENE ORGANISATION (PTY) LTD.}

P.O. BOX 28975

SANDRINGHAM 2131 JOHANNESBURG

Telephone (011) 640-5017

Die Suid-Afrikaanse Tydskrif vir Kommunikasieafwykings, Vol. 28, 1981 